\title{
FAKTOR - FAKTOR YANG MEMPENGARUHI PENYEMBUHAN LUKA EPISIOTOMI PADA IBU POST PARTUM DI PMB ISTIQOMAH SURABAYA
}

\author{
Intiyaswati* \\ STIKes William Booth SurabayaJl.Cimanuk No.20 Surabaya 60241 \\ intiyaswati21@gmail.com
}

\begin{abstract}
ABSTRAK
Episiotomi merupakan suatu tindakan insisi pada perineum yang menyebabkan terpotongnya selaput lendir vagina, cincin selaput darah dan jaringan pada septum rektovaginal. Episiotomi menyebabkan luka pada daerah perineum dan luka dapat menyebabkan perdarahan sehingga perlu dilakukan heacting. Pada proses penyembuhan luka di pengaruhi oleh faktor faktor yaitu budaya, personal hygine,pendidikan, ekonomi dan pengetahuan. Oleh karena itu dalam hal ini peneliti ingin melihat faktor - faktor yang mempengaruhi penyembuhan luka . Desain yang digunakan yaitu korelasi deskriptif, dengan tujuan untuk mengetahui adanya pengerahu penyembuhan luka dengan faktor budaya, personal hygine, pendidikan, ekonomi dan pengetahuan. Populasinya adalah seluruh ibu post partum yang mengalami luka episiotomi Sampel yang diambil sebanyak 30 dan di masukan rumus besaran sampel didapatkan 28 orang dan menggunakan sampling consecutive sampling. Dengan menggunakan variable dependen dan independen. Data hasil penelitian ini akan dimasukan menggunakan tabulasi silang. Hal ini menunjukkan bahwa terdapat perbedaan antara responden terhadap faktor - faktor penyembuhan luka episiotomi. Luka episiotomi ini di pengaruhi oleh faktor - faktor . Faktor yang mempengaruhi adalah faktor pengatahuan,ekonomi,pendidikan dan personal hygine. Dan yang tidak mempengaruhi adalah budaya. Faktor - faktor tersebut mempengaruhi tikah laku seseorang dalam mengambil keputusan mana yang benar dan salah dalam proses penyembuhan luka. Luka episiotomy di pengaruhi oleh faktor - faktor terhadap penyembuhan luka.
\end{abstract}

Kata kunci : episiotomy, budaya, personal hygine ,ekonomi, pendidikan dan pengetahuan.

\begin{abstract}
An episiotomy is an incision in the perineum action that causes injury vaginal mucous membrane, lining of blood and tissue ring relaction vaginal. Episiotomy cause injuries can cause bleending that needs to be done heacting. In the wound healing process influenced by factors factors of calture, sanitation, education, economis, and knowledge. Therefore in this case the researchers wanted to see factors - factors that affect would healting. The design used is descriptive coralation with the aim know. Influence wound healing with cultural factors, hygiene, education,economic and knowledge. The population is all post partum mother. The sample is taken by 30 and enter the sampel size formula in 28 people get and use sampling consecutive sampling. By using the independen and dependen variable. This research in cross talation of data to enter. This saggests that there are defferences between respondents. Factors factors affecting factors is factor hygine, education, economy, knowledge, and does not affect the culture. These factors affect a person's behavior in making decisions which are right and wrong in the process of would healting,
\end{abstract}

Keywords : episiotomy, culture, hygine, education, economy, and knowledge. 


\section{PENDAHULUAN}

Episiotomi merupakan suatu tindakan yang dilakukan dengan tujuan melahirkan bayi. Saat kepala bayi sudah terlihat $3-4$ $\mathrm{cm}$ di interitusvagina selama kontraksi. Episiotomy dilakukan pada kondisi tertentu seperrti gawat janin atau persalinan dengan penyulit atau jaringan parut pada perineum. Episiotomy yang digunakan dalam persalinan adalah episiotomy midialis. Episiotomy dimulai pada garis tengah komisura posterior lurus ke bawah tetapi tidak sampai serabut sfingter ani. Episiotomy medialis merupakan insisi pada garis tengah perineum ke arah rektum, yaitu ke arah tendesus perineum, memisahkan dua sisi otot perineum balbokavernosus. Otot tranversus parinei profunda jangan dapat dipisahkan tergantung kedalaman insisi. Bayak perempuan yang mengalami robekan perineum saat melahirkan baik pada primipara maupun multipara. Luka pada perineum bias terjadi akibat tindakan episiotomy. Luka episiotomy diidentik pada ibu post partum dapat sembuh normal dan ada yang mengalami kelambatan penyembuhan.. Luka episiotomy akan dijahit menggunakan benang catget dengan teknik penjahitan jelujur. Luka episiotomy dapat kering selama $7-10$ hari post partum. Untuk mempercepat penyembuhan luka episiotomy dapat dipengaruhi oleh beberapa faktor yaitu gizi, personal hygine, budaya, pendidikan, pengetahuan dan ekonomi, Pada BPS Istiqoma terdapat beberapa ibu post partum yang mengalami luka episiotomi dan pada kunjungan terdapat beberapa ibu post partum yang tidak sembuh luka episiotomi. Hasil wanwancara beberapa ibu post partum yang mengalami luka episiotomy yang tidak sembuh mengatakan bahwa ibu yang sudah melahirkan tidak boleh makanan makanan yang berbau amis ( telur, ikan, dan daging). Ibu mengikuti pantangan tersebut kerena ibu tidak tahu akibat dari pantang makanan yang dipantang. Salah satu ibu mengatakan tidak mampu membeli makanan seperti ikan dan daging. Dan beberapa ibu masih takut dalam membersihkan alat kelamin mereka menggunakan sabun dan air, hal ini didukung pula oleh tingkat ekonomi, pengetahuan dan pendidikan. Jika ibu dengan ekonomi rendah, pendididikan rendah dan pengetahuan rendah sulit dalam mengambil keputusan secara baik untuk penyembuhan luka.

Masyarakat yang masih mempercai budaya sangat mempengaruhi perilaku dan kebiasaan ibu, terutama pada ibu post partum. Dimana bayak larangan pada ibu post partum salah satunya adalah pantangan makanan. Hal tersebut membuat kebiasaan rutinitas ibu post partum. Di Indonesia tahun 2006 angka kejadian ibu post partum yang luka episiotomi tidak sembuh sekitar 35 - 45\% (Suorabowo,2006). Di Jawa Timur tahun 2000 angka kejadian ibu post partum 39,6\% yang mengalami lambatnya penyembuhan luka episiotomi. Di BPS Istikoma terdapat $20 \mathrm{ibu}$ post partum diantanya 15 ibu yang mengalami penyembuhan luka episiotomi yang lambat. Didapatkan hasil pemeriksaan luka ibu post parum luka epsiotomi yang lambat. Dari hasil pengkajian yang didaptkan, ibu masih mempertahankan budaya setempat dan ibu tidak memiliki pengetahuan yang luas yang msempengaruhi ibu untuk mengikuti budaya tersebut. Hal tersebut dilakukan karena didukung dengan ekonomiyang rendah sehingga ibu tidak mampu membeli makanan yang bergizi.

Luka episiotomi biasanya sembuh pada hari ke 7 sampai hari ke 10 post partum, luka episiotomi mulai mongering. Penjahitan luka episiotomi menggunakan benang catgut yang dapat menyatukan kembali luka episiotomy seperti semula. Dimana penyembuhan luka dapat sembuh total dengan cara menjaga kebersihan alat 
kelamin dan makanan yang bergizi terutama makanan yang mengandung protein sebab makanan yang mengandung protein dapat mempercepat penyembuhan luka. Jika ibu tidak melakukan hal tersebut maka luka episiotomi tidak dapat sembuh dengan cepat. Didapatkan dari hasil yang ada di lapangan terdapat ibu post partum yang mengalami penyembuhan luka yang sangat lambat. Jika tidak ditangani segera luka episiotomi tersebut akan menjadi merah, nyeri yang merupakan tanda - tanda dari infeksi..

Bayak cara untuk merawat luka episiotomi yaitu dengan menjaga kebersihan, terutama alat kelamin dengan cara mengganti pembalut kurang lebih dua kali sehari dan membersihkan alat kelamin menggunakan sabun dan air dari depan kebelakang setelah mandi, buang air kecil atau buang air besar. Selain kebersihan, nutrisi juga sangat penting dalam penyembuhan luka seperti makanan yang mengandung protein ( telur, ikan,dan daging). Dan makanan tersebut mudah di dapatkan.

\section{METODE}

Metode penelitian yang digunakan adalah desain deskritif korelatif yaitu suatu metode yang dilakukan dengan tujuan utama untuk hubungan korelatif antara variabel Variable dependen yaitu Penyembuhan luka episiotomy pada ibu post partum Luke episiotomy yang sembuh dengan cepat dan luka yang sembuh lama dengan menggunakan tanda REEDA dan variabel dependen Variabel independen faktor faktor yang mempengaruhi penyembuhan luka episiotomy (Personal hygine, Budaya, Pendidikikan, Ekonomi, Pengetahuan). Pengambilan data dengan menggunakan data primer yang diperoleh dari hasil kuesioner.
Populasi dalam penelitian ini adalah Seluruh ibu post partum yang mengalami luka episiotomi di BPS Istikomah. Teknik sampling yang digunakan dalam penelitian ini adalah Menggunakan consecutive sampling. Penelitian ini menggunakan kuesioner sebagai intrumen. Pengolahan data dilakukan dengan cara : editing, coding, tabulating, scoring.

\section{HASIL}

\section{Data Umum}

Pada data umum ini disajikan karakteristik responden berdasarkan pendidikan, pendapatan keluarga, pekerjaan ibu, jumlah anak, dan umur yang mempengaruhi penyembuhan luka episiotomi di BPS Istiqomah

1 Karakteristik Responden Terhadap Pendidikan

Table.1 Karakteristik Responden Pada Ibu Post Partum BerdasarkanTingkat Pendidikan Di BPS Istiqomah

\begin{tabular}{|c|c|c|c|}
\hline $\begin{array}{c}\text { N } \\
\mathrm{o}\end{array}$ & $\begin{array}{c}\text { Pendidika } \\
\mathrm{n}\end{array}$ & $\begin{array}{c}\text { Jumla } \\
\mathrm{h}\end{array}$ & $\begin{array}{c}\text { Prosenta } \\
\text { se }\end{array}$ \\
\hline 1 & SD & 10 & $36 \%$ \\
\hline 2 & SMP & 10 & $36 \%$ \\
\hline 3 & SMA & 8 & $29 \%$ \\
\hline 4 & PT & 0 & 0 \\
\hline 5 & $\begin{array}{c}\text { Tidak } \\
\text { sekolah }\end{array}$ & 0 & 0 \\
\hline \multicolumn{2}{|c|}{ Total } & 28 & $100 \%$ \\
\hline
\end{tabular}

Berdasarkan Tabel.1 menunjukan bahwa pendidikan ibu yang terbayak adalah SD yaitu sebayak 10 responden $(35,7 \%)$ dan SMP yaitu sebayak 10 responden $(35,7 \%)$.

2. Karakteristik Responden Terhadap Penghasilan 
Tabel 2. Karakteristik Responden Berdasarkan penghasilan DI BPS Istiqomah

\begin{tabular}{|c|c|c|c|}
\hline No & Pengahasilan & Jumlah & Prosentase \\
\hline 1 & $<1.000 .000$ & 7 & $25 \%$ \\
\hline 2 & $\begin{array}{c}1.000 .000- \\
2.000 .000\end{array}$ & 20 & $71 \%$ \\
& $>2.000 .000$ & 1 & $4 \%$ \\
\hline 3 & Total & 28 & $100 \%$ \\
\hline \multicolumn{2}{|c|}{}
\end{tabular}

Berdasarkan Tabel .2 menunjukan bahwa penghasilan ibu terbanyak adalah 1.000 .000 - 2.000.000 yaitu sebayak 20 responden $(71 \%)$.

3 Karakteristik Responden Berdasarkan Pekerjaan Ibu

Tabel.3 Karakteristik Responden Pada Berdasarkan Pekerjaan Di BPS Istiqomah

\begin{tabular}{|c|c|c|c|}
\hline No & Pekerjaan & Jumlah & Prosentase \\
\hline 1 & Pegawai Negri & 8 & $28.6 \%$ \\
\hline 2 & Pedagang & 9 & $32.1 \%$ \\
\hline 3 & Petani & 10 & $35.7 \%$ \\
\hline 4 & Tidak Bekerja & 1 & $3.6 \%$ \\
\hline \multicolumn{2}{|c|}{ Total } & 28 & $100 \%$ \\
\hline
\end{tabular}

Berdasarkan Tabel.3 menunjukan bahwa pekerjaan ibu terbanyak adalah petani sebayak 10 responden $(35,7 \%)$.

\section{Karakteristik Responden Terhadap} Jumlah Anak

Table 4. Karakteristik Responden Berdasarkan Jumlah anak Di BPS Istiqomah

\begin{tabular}{|c|c|c|c|}
\hline No & Anak Ke & Jumlah & $\begin{array}{c}\text { Prosent } \\
\text { ase }\end{array}$ \\
\hline 1 & Pertama & 15 & $53.6 \%$ \\
\hline 2 & Kedua & 12 & $42.9 \%$ \\
\hline 3 & Lebih Dari Dua & 1 & $3.6 \%$ \\
\hline \multicolumn{2}{|c|}{ Total } & 28 & $100.0 \%$ \\
\hline
\end{tabular}

Berdasarkan Tabel.4 menunjukan bahwa jumlah anak terbanyak adalah anak pertama yaitu 15 responden $(53,6 \%)$.

5 Karakteristik Responden Terhadap Umur

Tabel.5 Karakteristik Respondeni

Berdasarkan Umur Di BPS Istiqomah

\begin{tabular}{|l|l|l|l|}
\hline No & Umur & Jumlah & Prosentase \\
\hline 1 & $17-25$ tahun & 14 & $50 \%$ \\
\hline 2 & $26-35$ tahun & 13 & $46 \%$ \\
\hline 3 & $36-40$ tahun & 1 & $4 \%$ \\
\hline 4 & Lebih dari 40 tahun & 0 & $0 \%$ \\
\hline \multicolumn{2}{|l|}{ Total } & 28 & $100 \%$ \\
\hline
\end{tabular}

Berdasarkan Tabel.5 menunjukan bahwa umur ibu terbanyak adalah $17-25$ tahun yaitu 14 responden $(50 \%)$.

\section{Data Khusus}

1 Karasteristik Responden Terhadap Personal Hygine

Tabel 1 Karakteristik Responden Berdasarkan Pengethuan Di BPS Istiqomah

\begin{tabular}{|l|l|l|l|}
\hline No & Personal Hygine & Jumlah & Prosentase \\
\hline 1 & Baik & 10 & $36 \%$ \\
\hline 2 & Buruk & 18 & $64 \%$ \\
\hline \multicolumn{2}{|l|}{ Total } & 28 & $100 \%$ \\
\hline
\end{tabular}

Berdasarkan Tabel 1 menunjukan bahwa personal hygine ibu terbanyak adalah buruk yaitu 18 responden $(64 \%)$.

2 Karakteristik Responden Terhadap Budaya Tabel 2. Karakteristik Responden Berdasarkan Budaya Di BPS Istiqomah

\begin{tabular}{|l|l|l|l|}
\hline No & Budaya & Jumlah & Porsentase \\
\hline 1 & Setuju & 2 & $7 \%$ \\
\hline 2 & Tidak setuju & 26 & $93 \%$ \\
\hline \multicolumn{2}{|l|}{ Total } & 28 & $100 \%$ \\
\hline
\end{tabular}

Berdasarkan Tabel 2 menunjukan budaya ibu terbanyak adalah tidak setuju 26 responden $(93 \%)$. 
3 Karakteristik Responden Terhadap Pengetahuan

Tabel 3 Karakteristik Responden Berdasarkan Pengetahuan Di BPS Istiqomah

\begin{tabular}{|l|l|l|l|}
\hline No & Pengetahuan & Jumlah & Porsentase \\
\hline 1 & Baik & 0 & 0 \\
\hline 2 & Sedang & 6 & $25 \%$ \\
\hline 3 & Kurang & 22 & $71 \%$ \\
\hline \multicolumn{2}{|l|}{ Total } & 28 & $100 \%$ \\
\hline
\end{tabular}

Berdasarkan Tabel 3 menunjukan bahwa pengetahuan ibu terbanyak adalah kurang yaitu sebayak 22 responden (71\%).

4. Karakteristik Responden Terhadap Penyembuhan Luka

Tabel 4. Karakteristik Responden Berdasarkan Penyembuhan Luka Di BPS Istiqomah

\begin{tabular}{|l|l|l|l|}
\hline No & $\begin{array}{l}\text { Penyembuhan } \\
\text { luka }\end{array}$ & Jumlah & Porsentase \\
\hline 1 & Baik & 7 & $25 \%$ \\
\hline 2 & Buruk & 21 & $75 \%$ \\
\hline \multicolumn{2}{|l}{ Total } & 28 & $100 \%$ \\
\hline
\end{tabular}

Berdasarkan Tabel 4. menunjukkan penyembuhan luka ibu yang terbanyak adalah buruk yaitu 21 responden (75\%).

\section{Data Tabulasi Silang}

1. Personal Hygine Dengan Penyembuhan Luka

Tabel 1 Tabulasi Silang Berdasarkan Faktor Personal Pada Responden Yang Mempengaruhi Penyembuhan Luka DI BPS Istiqomah

\begin{tabular}{|l|l|l|l|l|l|}
\hline $\begin{array}{l}\text { Pexyembuhan } \\
\text { Luka }\end{array}$ & Baik & $\%$ & Buruk & $\%$ & Total \\
$\begin{array}{l}\text { Personal } \\
\text { Hygine }\end{array}$ & 5 & $28 \%$ & 13 & $72 \%$ & 18 \\
\hline Baik & 5 & $20 \%$ & 8 & $80 \%$ & 10 \\
\hline Buruk & 2 & & 21 & & 28 \\
\hline Total & 7 & & \multicolumn{3}{|c}{} \\
\hline
\end{tabular}

Pada tabel 1 meenunjukkan bahwa faktor personal hygine personal hygine hampir seluruhnya mempengaruhi penyembuhan luka dibuktikan dengan tabulasi silang responden yaitu penyembuhan luka buruk dengan personal hygien buruk sebanyak 8 responden $(80 \%)$.

2. Budaya Dengan Penyembuhan Luka Tabel 2 Tabulasi Silang Berdasarkan Faktor Budaya Pada Responden Yang Mempengaruhi Penyembuhan Luka DI BPS Istiqomah

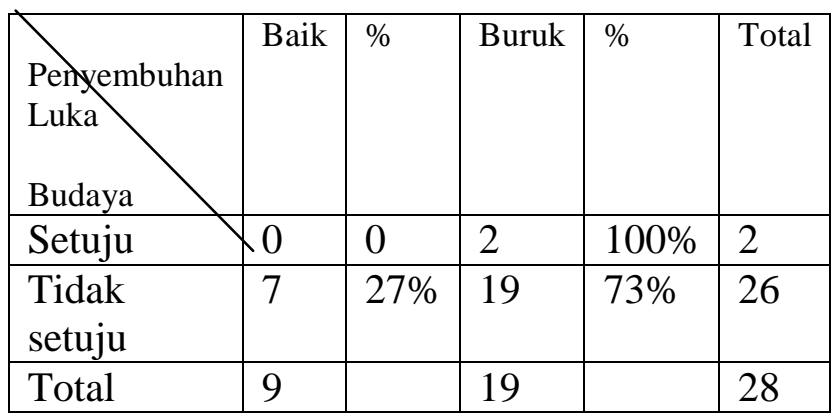

Pada tabel 2. meenunjukkan bahwa faktor budaya tidak mempengaruhi penyembuhan luka dibuktikan dengan tabulasi silang responden yaitu penyembuhan luka buruk, setuju dengan budaya sebanyak 2 responden $(100 \%)$.

3 Pendidikan Dengan Penyembuhan Luka Tabel 3. Tabulasi Silang Berdasarkan Faktor Pendidikan Pada RespondenYang Mempengaruhi Penyembuhan Luka Di BPS Istiqomah.

\begin{tabular}{|c|c|c|c|c|c|}
\hline $\begin{array}{l}\text { Penyembuhan } \\
\text { Luka }\end{array}$ & Baik & $\%$ & Buruk & $\%$ & Total \\
Pendidikan & & & & & \\
\hline SD & 3 & $30 \%$ & 7 & $70 \%$ & 10 \\
\hline SMP & 1 & $10 \%$ & 9 & $90 \%$ & 10 \\
\hline SMA & 3 & $38 \%$ & 5 & $62 \%$ & 8 \\
\hline PT & 0 & 0 & 0 & 0 & 0 \\
\hline $\begin{array}{c}\text { Tidak } \\
\text { sekolah }\end{array}$ & 0 & 0 & 0 & 0 & 0 \\
\hline Total & 7 & & 21 & & 28 \\
\hline
\end{tabular}


Pada tabel 3. meenunjukkan bahwa faktor pendidikan hampir seluruhnya mempengaruhi penyembuhan luka dibuktikan dengan tabulasi silang responden yaitu penyembuhan luka buruk dengan pendidikan SMP sebanyak 9 responden (90\%).

4. Penghasilan Dengan Penyembuhan Luka Table 4. Tabulasi Silang Berdasarkan Faktor Penghasilan Pada Responden Yang Mempengaruhi Penyembuhan Luka Di BPS Istiqomah.

\begin{tabular}{|c|c|c|c|c|c|}
\hline $\begin{array}{l}\text { Penyembuhan } \\
\text { Luka }\end{array}$ & Baik & $\%$ & Buruk & $\%$ & Total \\
Pengahasilan & & & & & \\
\hline Rendah & 0 & & 7 & $100 \%$ & 7 \\
\hline Sedang & 6 & $29 \%$ & 14 & $70 \%$ & 20 \\
\hline Tinggi & 1 & $100 \%$ & 0 & & 1 \\
\hline Total & 7 & & 21 & & 28 \\
\hline
\end{tabular}

Pada tabel 4. menunjukkan bahwa faktor ekonomi seluruhnya mempengaruhi penyembuhan luka dibuktikan dengan tabulasi silang responden yaitu penyembuhan luka buruk dengan ekonomi rendah sebanyak 7 responden (100\%)

5. Pengetahuan Dengan Penyembuhan Luka Tabel 5. Tabulasi Silang Berdasarkan Faktor Pengetahuan Pada Responden Yang Mempengaruhi Penyembuhan Luka Episiotomi Terhadap Penyembuhan Luka Di BPS Istiqomah

\begin{tabular}{|c|c|c|c|c|c|}
\hline $\begin{array}{c}\text { Penyembuha } \\
\text { n Luka }\end{array}$ & $\begin{array}{c}\text { Bai } \\
\mathrm{k}\end{array}$ & $\begin{array}{c}\% \\
\text { Pengetahuan }\end{array}$ & $\begin{array}{c}\text { Buru } \\
\mathrm{k}\end{array}$ & $\begin{array}{c}\text { Tota } \\
1\end{array}$ \\
\hline Baik & 0 & 0 & 0 & 0 & 0 \\
\hline Sedang & 2 & $\begin{array}{c}33 \\
\%\end{array}$ & 4 & $\begin{array}{c}67 \\
\%\end{array}$ & 6 \\
\hline Kurang & 5 & $\begin{array}{c}23 \\
\%\end{array}$ & 17 & $\begin{array}{c}77 \\
\%\end{array}$ & 22 \\
\hline Total & 7 & & 21 & & 28 \\
\hline
\end{tabular}

Pada Tabel 5. menunjukkan bahwa faktor pengetahuan hampir seluruhnya mempengaruhi penyembuhan luka dibuktikan dengan tabulasi silang responden yaitu penyembuhan luka buruk dengan pengetahuan kurang sebanyak 17 responden $(77 \%)$.

\section{Pembahasan}

Pada pembahasan ini akan diuraikan hasil penelitian Berdasarkan Tabulasi Silang1-5 didapatkan hasil bahwa faktor - faktor yang mempengaruhi penyembuhan antara lain faktor pengetahuan, faktor personal hygine, budaya, ekonomi, dan pendidikan. Faktor yang paling mempengaruhi ibu dalam penyembuhan luka episiotomi adalah faktor pengetahuan dan tidak mempengaruhi adalah budaya dimana jumlah penyembuhan luka buruk yang memiliki tingkat pengetahuan kurang adalah sebayak 17 responden $(77 \%)$ dan setuju dengan budaya sebayak 2 responden $1(00 \%)$.

\section{Menurut Soekidjo}

menyatakan ada dua faktor yang mempengaruhi penyembuhan luka yaitu internal dan eksternal. Faktor internal yang terdiri dari pengetahuan, personal hygin, ekonomi, pengetahuan dan jumlah anak. Sedangkan faktor eksternal adalah budaya. Hal ini menunjukkan bahwa dalam penyembuhan luka ada beberapa faktor yang mempengaruhi yaitu faktor internal dan tidak di pengaruhi faktor eksternal.

\section{Personal Hygine Dengan \\ Penyembuhan Luka}

Pada tabel 1 menunjukkan bahwa faktor personal hygine personal hygine hampir seluruhnya mempengaruhi penyembuhan luka dibuktikan dengan tabulasi silang responden yaitu penyembuhan luka buruk dengan personal hygien buruk sebayak 8 responden $(80 \%)$. Perawatan khusus perinial bagi wanita setelah melahirkan anak mengurangi rasa ketidak nyamanan, 
kebersihan, mencegah infeksi dan meningkatkan penyembuhan dengan prosedur pelaksanan menurut Hamilton ( 2002) adalah sebagai berikut :Mencegah kontaminasi dari rectum,menangani dengan lembut pada jaringan yang terkena trauma, bersihkan semua keluaran yang menjadi sumber bakteri dan bau. Perawatan perineum yang tidak benar menyebabkan infeksi dan memperlambat penyembuhan. Personal hygine yang yang benar yaitu alat kelamin di besihkan saat mandi, BAB / BAK, membersihkan menggunakan sabun antiseptic dari depan ke belakang. Jika tidak di bersihkan secara baik maka dapat terjadi infeksi akibat dari terkontaminasi kuman pada rectum. Maka para ibu di anjurkan untuk membersihkan secara benar yaitu menggunakan sabun antiseptic dan air dari depan ke belakang .selain itu juga pengalaman ibu juga sangat berpengaruh dalam cara membersihkan alat kelamin yaitu disini paling bayak responden yang mempunyai anak pertama. Hal ini mempengaruhi ibu dalam proses penyambuhan luka karena pengalaman merupa guru besar,sehingga personal hygine juga di pengaruhi oleh pengalaman ibu dalam proses penyembuhan luka.

2. Budaya Dengan Penyembuhan Luka Pada tabel 2. menunjukkan bahwa faktor budaya tidak mempengaruhi penyembuhan luka dibuktikan dengan tabulasi silang responden yaitu penyembuhan luka buruk, setuju dengan budaya sebayak 2 responden (100\%).Menurut Creasoft (2002) bahwa penyembuhan luka di pengaruhi oleh beberapa faktor internal dan eksternal. salah satunya faktor eksternal yeng mempengaruhi penyembuhan luka episiotomy antara lain budaya. Menurut Koentjaraningrat budaya adalah suatu system gagasan dan rasa, tindakan serta karya yang dihasilkan manusia dalam kehidupan bermasyarakat yang di jadikan miliknya dengan belajar. Menurut E.B.Taylor budaya adalah suatu keeluruhan kompleks yang meliputi pengetahuan, kepercayaan, seni kesusiaan, hukum adat istiadat,serta kesanggupan dan kebiasaan lainnya yang dipelajari manusia sebagai anggota masyarakat. Budaya di Indonesia masih sangat melekat pada masyarakat sekarang, yang di buktikan pada oleh creasoft ramuan peninggalan nenek moyang dan larangan mengkonsumsi suatu jenis makanan tertentu, merupakan budaya yang di anut oleh masyarakat terbut karena hal tersebut merupakan kepercayaan dan kebiasaan masyarakat. Pada perkembangan zaman yang modern ini budaya masih di pecayai oleh masyarakat dan dilakukan secara terus menerus. Dari data tabulasi silang penyembuhan luka tidak mempengaruhi penyembuhan luka hal ini di sebabkan bukan hanya faktor buadaya yang mempengaruhi penyembuhan luka yaitu beberapa faktor salah satunya adalah personal hygine.

\section{Faktor Pendidikan Pada RespondenYang Mempengaruhi Penyembuhan Luka}

Pada tabel 3. menunjukkan bahwa faktor pendidikan hampir seluruhnya mempengaruhi penyembuhan luka dibuktikan dengan tabulasi silang responden yaitu penyembuhan luka buruk dengan pendidikan SMA sebayak 9 responden (90\%).Menurut Prof. Dr. Jihn Dewey. Pendidikan adalah suatu proses pengalaman. Karena kehidupan adalah pertumbuhan, pendidikan berarti membantu pertumbuhan batin tanpa dibatasi oleh usia. Proses pertumbuhan ialah proses penyesuaian pada tiap - tiap fase serta menambah kecakapan di dalam perkembangan seseorang. Di dapatkan hasil sebayak 10 responden $(35,7 \%)$ dimana sebarannya pada 9 respnden yang penyembuhan lukanya buruk dan 1 responden yang penyembuhan lukanya baik. Dimana tingkat pendidikan seseorang semakin tinggi maka mudah menerima informasi dan dapat mengambil keputusan 
yang baik dan benar untuk kesembuhan luka ibu. Sedangkan yang berpendidikan rendah sulit menerima informasi dan tidak dapat mengambil suatu keputusan yang baik dan benar untuk kesembuhan luka ibu.

\section{Penghasilan Dengan Penyembuhan Luka}

Pada tabel 4. meenunjukkan bahwa faktor ekonomi hampir seluruhnya mempengaruhi penyembuhan luka dibuktikan dengan tabulasi silang responden yaitu penyembuhan luka buruk dengan ekonomi rendah sebayak 7 responden (100\%). Menurut para ahli Markus dan Wijaya pendapatan adalah nilai suatu usaha yang dilakukan orang perorang berupa uang dari tambahan kemempuan ekonomis netto seseorang antara dua titik.Pangaruh ekonomi dengan lamanya penyembuhan luka adaah keadaan fisik dan mental ibu dalam melakukan aktifitas sehari hari pasca persalinan. Jika ibu memiliki ekonomi yang rendah, dapat menyebabkan penyembuhan luka yang berlangsung lama karena timbul rasa malas dalam merawat diri. Dimana ibu yang ekonominya rendah tidak dapat menunjang ibu dlam menyediakan sarana dan prasarana dalam melakukan perawatan perineum, misalnya kemampuan ibu dalam menyediakan antiseptic.

\section{Pengetahuan Dengan Penyembuhan Luka}

Pada Tabel 5. menunjukkan bahwa faktor pengetahuan hampir seluruhnya mempengaruhi penyembuhan luka dibuktikan dengan tabulasi silang responden yaitu penyembuhan luka buruk dengan pengetahuan kurang sebayak 17 responden (77\%).Menurut Soekidjo (2003) pengetahuan ialah "tahu" dan ini terjadi setelah orang melakukan penginderaan terhadap suatu objek tertentu. Pengatahuan sangat penting untuk terbentuknya suatu sikap seseorang. Di harapkan ibu yang memiliki tingkat pengetahuan baik dan sedang mampu mencari dan meneima informasi yang di dapatkan. Tingakat pengetahuan ibu dapat dipengaruhi oleh beberapa faktor seperti pengalaman memiliki anak dan kemempuan merawat luka maupun pengalaman dari ibu yang lain dalam perawata luka episotomi. Ibu dapat memperolehi informasi dari media elektronik maupun cetak. Dengat tingkat pengetahuan ibu baik, seperti mengetahuan manfaat perawatan atau kebersihan dan makanan untuk kesembuhan luka maka keputusan untuk melakukan hal tersebut akan menjadi manfaat bagi penyembuhan luka ibu

\section{Simpulan}

1. Faktor pengetahuan mempengaruhi penyembuhan luka episiotomi Responden pada BPS Istiqomah

2. Faktor personal hygine mempengaruhi penyembuhan luka episiotomy responden pada BPS Istiqomah

3. Faktor budaya tidak mempengaruhi penyembuhan luka episiotomi responden pada BPS Istiqomah

4. Faktor pendidikan mempengaruhi penyembuhan luka episiotomi responden pada BPS Istiqomah

5. Faktor ekonomi mempengaruhi penyembuhan luka episiotomi responden pada BPS Istiqomah

\section{Saran}

Berdasarkan hasil penelitian yang telah dilakukan maka saran - saran yang di perlukan di perhatikan.

\section{Bagi BPS Istiqomah}

Dengan hasil penelitian ini dapat di jadikan refrensi untuk memperbaiki penyembuhan luka pada ibu post partum di BPS istikoma yaitu dengan cara memberikan penyeluhan tentang makanan yang berzi, cara membersihkan perineum, budaya tidak harus dilakukan dan memberikan leaflet cara 
membersihkan alat kelamin dan proses penyembuhan luka.

\section{Bagi institusi}

Diharapkan hasil penelitian ini dapat digunakan sebagai refrensi di perpustakaan untuk meningkatkan pengetahuan mahasiwa di stikes William Booth Surabaya.

3. Bagi Peneliti Selanjutnya

Perlu di adakan penelitian lebih lanjut tentang penyembuhan luka episiotomy pada ibu post partum dengan memperluas faktor - faktor yang mempengaruhi penyembuhan luka episiotomy dengan variabel lain, karena dalam penelitian ini waktunya cukup singkat.

\section{DAFTAR PUSTAKA}

Arikunto suharsimi. (2006). Prosedur Penelitian suatu Pendekatan Praktik, Edisi Revisi VI. Rineke Cipta .

Bobak, Lowdermik, jensen. (2004). Buku Ajar Keperawatan Maternitas. Jakarta : EGC.

Yayasan Bina Pustaka Sarwono Prawirohardjo. (2002). Buku Panduan PraktisPelayanan Kesehatan Maternal dan Neonatal. Tridasa Printer : Jakarta.

Doenges.(2001). Rencana Perawatan Maternal/Bayi, Pedoman untuk Perencanaan dan Dokumentasi Perawatan Klien. EGC: Jakarta

David T.Y. Liu. (2007). Manual Persalinan. EGC : Jakarta.

F. Gary Cunningham, dkk. (2005). Obstetri Wiliams. EGC : Jakarta.

Fraser M. Diane, dkk. (2009). Buku Ajar Bidan Edisi 14. EGC : Jakarta.
Manuaba I.B.G, Manuaba Chandranita, Manuaba Fajar. (2007). Pengantar Kuliah Obstetri. EGC : Jakarta.

Nursalam. (2003). Konsep dan Penerapan Meteodologi Penelitian Ilmu Keperawatan Nursalam. Salemba Medika : Jakarta.

Hanifa, Winkjosastro.( 2008). Ilmu Kebidanan. Yayasan Bina Pustaka Sarwono: Jakarta

Prawirohardjo Sarwono. ( 2002) . Pelayanan Kesehatan Maternatal dan Neonatal. YBPSP: Jakarta.

Prawirohardjo S. (2005). Ilmu Kebidanan. Yayasan Bina Pustaka Sarwono Prawirohardjo : Jakarta. 